\title{
Musculoskeletal disorders in banana culture workers
}

\author{
Distúrbios osteomusculares em trabalhadores da bananicultura
}

José Martim Marques Simas ${ }^{1}$, Maria do Carmo Baracho de Alencar ${ }^{1}$, Liria Yuri Yamauchi²

DOI 10.5935/2595-0118.20200008

\section{ABSTRACT}

BACKGROUND AND OBJECTIVES: Work-related repetitive strain injury/musculoskeletal disorders affect numerous rural workers causing functional physical impairment. This study aimed to investigate the prevalence of work-related musculoskeletal disorders in banana culture workers.

METHODS: From a list of banana culture workers linked to the Family Strategy, a questionnaire was applied to obtain socio-demographic data, rural property, health and labor, and the Nordic Musculoskeletal Questionnaire. Data were statistically analyzed using the statistical software R Development Core Team .

RESULTS: Thirty-six workers from ten rural properties participated in the study. The majority were male (94.4\%), age group from 20 to 49 years $(75.0 \%)$, most of them with incomplete primary education $(50.0 \%)$. Regarding musculoskeletal disorders, the main regions affected were lumbar (63.9\%), shoulders (47.2\%) and knees (44.4\%), with more than one region affected per worker. Regarding the work, tasks were described as painful and tiring including cutting, loading, fertilization, costal pulverization of pesticide, plowing and thinning.

CONCLUSION: There are risks of musculoskeletal disorders among banana workers with risks of leave of absence due to illness, which may lead to losses in daily activities. There is a need to deepen the theme to promote health at work.

Keywords: Agriculture, Musculoskeletal pain, Occupational health, Rural population health.

José Martim Marques Simas - Dhttps://orcid.org/0000-0003-1742-3707;

Maria do Carmo Baracho de Alencar - Dhttps://orcid.org/0000-0001-7555-4153;

Liria Yuri Yamauchi - Dhttps://orcid.org/0000-0002-2790-0266.

1. Universidade Federal de São Paulo, Departamento de Saúde, Educaçấo e Sociedade, Santos, SP, Brasil.

2. Universidade Federal de Sáo Paulo, Departamento de Ciências do Movimento Humano, Santos, SP, Brasil.

Submitted on July $01,2019$.

Accepted for publication on December 16, 2019.

Conflict of interests: none - Sponsoring sources: Fundação de Amparo à Pesquisa do Estado de São Paulo- FAPESP.

Correspondence to:

José Martim Marques Simas

UNIFESP/BS - Departamento de Saúde, Educaçáo e Sociedade

Av. Silva Jardim, 136, Vila Mathias

11015-020 Santos, SP, Brasil.

E-mail:simasjmm@gmail.com / j.simas@unifesp.br

(C) Sociedade Brasileira para o Estudo da Dor

\section{RESUMO}

JUSTIFICATIVA E OBJETIVOS: As lesões por esforços repetitivos/distúrbios osteomusculares relacionados ao trabalho têm afetado inúmeros trabalhadores rurais, ocasionando comprometimentos funcionais. O objetivo deste estudo foi investigar a prevalência de distúrbios osteomusculares relacionados ao trabalho na bananicultura.

MÉTODOS: Foi obtida a listagem de trabalhadores vinculados à Estratégia da Família e foram aplicados um questionário para obter dados sociodemográficos, da propriedade rural, de saúde e trabalho; e o Questionário Nórdico de Sintomas Osteomusculares. Os dados foram analisados estatisticamente por meio do programa estatístico $R$ Development Core Team.

RESULTADOS: Participaram da pesquisa 36 trabalhadores de 10 propriedades rurais, sendo a maioria do sexo masculino (94,4\%), com faixa etária entre 20 e 49 anos $(75,0 \%)$, e ensino fundamental incompleto $(50,0 \%)$. Em relação aos distúrbios osteomusculares, as principais regiôes acometidas foram: lombar $(63,9 \%)$; ombros $(47,2 \%)$ e joelhos $(44,4 \%)$, havendo mais uma região acometida por trabalhador. No trabalho, foram relacionadas tarefas penosas/cansativas junto ao corte, carregamento, adubação, pulverização costal de agrotóxico, roçado e desbaste.

CONCLUSÁO: Há riscos de distúrbios osteomusculares entre os trabalhadores da bananicultura, com riscos de afastamento do trabalho e prejuízos em atividades cotidianas. Há necessidade de aprofundar o tema visando a promoçấo da saúde do trabalhador. Descritores: Agricultura, Dor musculoesquelética, População do campo, Saúde do trabalhador.

\section{INTRODUCTION}

Work-related repetitive strain injuries/musculoskeletal disorders (RSI/WRMD) cover 53\% of occupational illnesses recorded at European Union ${ }^{1}$ and $26 \%$ at US ${ }^{2}$, according to data of 2014 and 2015, leading a large part of individuals to sick leave. RSI/ WRMD-related leaves in Brazil have high prevalence, representing around $12 \%$ of all benefits granted by the National Institute of Social Security (INSS) in $2017^{3}$.

These conditions are caused by overuse of the musculoskeletal system and are directly related to the task demands, the physical and organizational work environments ${ }^{4}$. RSI/WRMD affects men and women in the productive phase of their lives, causing pain, suffering and functional disability, leading to work leave and disability retirement ${ }^{5}$. They are highlighted by the functional physical impairment in the individuals' lives, leading to changes in activities of daily living ${ }^{4}$. Among the risk factors are the 
workload, accelerated production demand, lack of rest breaks, evaluation and punishment modes for production control ${ }^{4,5}$. When chronic, RSI/WRMD causes sick leave for short and/or long periods $s^{6}$. There is a high prevalence of musculoskeletal disorders in agricultural workers, mainly affecting the lower back and upper limbs ${ }^{7-10}$. In banana farming, due to work demands, there are correlations between work and the presence of musculoskeletal disorders ${ }^{11,12}$.

The purpose of this study was to investigate the prevalence of WRMD in banana farming in the region of Registro, state of São Paulo.

\section{METHODS}

This is a cross-sectional observational study with a descriptive approach, which was conducted with workers from rural properties in the municipality of Registro, located in Vale do Ribeira, in the state of São Paulo, from December 2018 to April 2019. A list of individuals linked to rural neighborhoods within the sanitary territory of Jardim São Paulo's Family Health Strategy (FHS) was obtained, and the workers were subsequently selected, having as inclusion criteria to work in banana farming for a minimum of three months, for the sake of working relationships. Exclusion criteria were working time in banana farming less than three months and the presence of WRMD before working in banana farming.

Visits were made to workplaces and/or homes, as well as telephone contacts, and the study proposal was presented to the owner and workers, and the invitation for voluntary participation was made. After the consent of the worker, the pre-drafted questionnaire was applied, in an individual interview, containing sociodemographic data, such as gender, marital status, schooling, family income; about the rural property: number of workers/rural property, size of rural property in hectares in general and in agricultural production; and about the work: type of work contract, working time in banana farming, presence of muscle fatigue, over-tiredness, and painful and tiring tasks; and the Nordic Musculoskeletal Questionnaire (NMQ), validated in Brazil ${ }^{13}$. In the application of this instrument, the individual reported the occurrence of musculoskeletal symptoms considering the last 12 months and seven days preceding the investigation, also reporting the occurrence of leave from daily activities in the previous year.

The study was approved by the Research Ethics Committee of the Federal University of São Paulo, under opinion No. 2,877,092 of September 5, 2018. The participants signed the Free and Informed Consent Form (FICT).

\section{Statistical analysis}

Collected data were analyzed using the $R$ Development Core Team statistical program.

\section{RESULTS}

Thirty-six individuals from 10 rural properties in the region attached to the FHS of Jardim Sâo Paulo participated in the research, corresponding to $95 \%$ of the banana farming workers in the region, as two workers could not participate in the study. The municipality of Registro is responsible for over $60 \%$ of all banana production in the state of Sáo Paulo ${ }^{14}$, and Brazil is considered the largest consumer of "in natura" bananas and the fourth largest fruit producer in the world ${ }^{15}$. This corresponds to $7 \%$ of world production, being the largest banana exporter, with more than two-thirds of production exported to other countries ${ }^{16}$.

Each rural property had, on average, four workers $(\mathrm{SD}=2.8)$, with 22.2 hectares of land $(\mathrm{SD}=7.5)$ devoted exclusively to banana farming. From the 10 participating rural properties, only three of them had other productions besides banana, such as the cultivation of pupunha palm heart and ornamental plants. Only two farms were family farming; the others were commercial far$\mathrm{ms}$ with employers and employees.

Most individuals (94.4\%) were male, cohabiting or married $(86.1 \%)$, with one child $(38.7 \%)$ and incomplete elementary education (50.0\%). Most of them had a family income of 1 to 2 minimum wages $(71.4 \%)$, and $33.3 \%$ had an informal employment contract. The average working time in the banana farming was 11.8 years, most of them between 1 - and 5 -years (30.6\%).

The data obtained regarding musculoskeletal disorders are shown in table 1.

Table 1. Musculoskeletal disorders, divided by affected body regions, period and body segment that led to some work leave

\begin{tabular}{lccc}
\hline $\begin{array}{l}\text { Affected body } \\
\text { regions }\end{array}$ & $\begin{array}{c}\text { Last 12 } \\
\text { months }\end{array}$ & $\begin{array}{c}\text { Last } 7 \\
\text { days }\end{array}$ & $\begin{array}{c}\text { Work leave in the } \\
\text { previous 12 months }\end{array}$ \\
\hline Cervical & $33.3 \%$ & $30.8 \%$ & $23.1 \%$ \\
Shoulders & $47.2 \%$ & $52.9 \%$ & $23.5 \%$ \\
$\begin{array}{l}\text { Elbows } \\
\text { Fists and/or }\end{array}$ & $13.9 \%$ & $28.6 \%$ & $0.0 \%$ \\
hands & $38.9 \%$ & $53.3 \%$ & $28.6 \%$ \\
$\begin{array}{l}\text { Thoracic } \\
\text { Lumbar }\end{array}$ & $41.7 \%$ & $50.0 \%$ & $12.5 \%$ \\
$\begin{array}{l}\text { Hips and/or } \\
\text { thighs }\end{array}$ & $30.6 \%$ & $40.0 \%$ & $16.7 \%$ \\
Knees & $44.4 \%$ & $68.8 \%$ & $8.3 \%$ \\
$\begin{array}{l}\text { Ankles and/or } \\
\text { feet }\end{array}$ & $27.8 \%$ & $60.0 \%$ & $31.3 \%$ \\
\hline
\end{tabular}

Note: There was more than one body region affected by worker.

In the NMQ, the main regions affected were lumbar (63.9\%), shoulders (47.2\%), and knees (44.4\%). Concerning the last seven days, there was a higher prevalence for the knees $(68.8 \%)$, shoulders (52.9\%), and ankles/feet (60.0\%). Regarding the impairment to performing daily tasks as a result of musculoskeletal symptoms, there was evidence of work leaves due to involvement, especially of the ankles/feet (50.0\%), knees (31.3\%) and wrists/hands regions (28.6\%). In addition, among the respondents, $38.9 \%$ reported muscle fatigue, $41.7 \%$ over-tiredness, and $86.1 \%$ complained of painful and/or tiring tasks at work in banana farming.

The main painful and tiring work tasks related to musculoskeletal disorders are shown in figure 1 . 


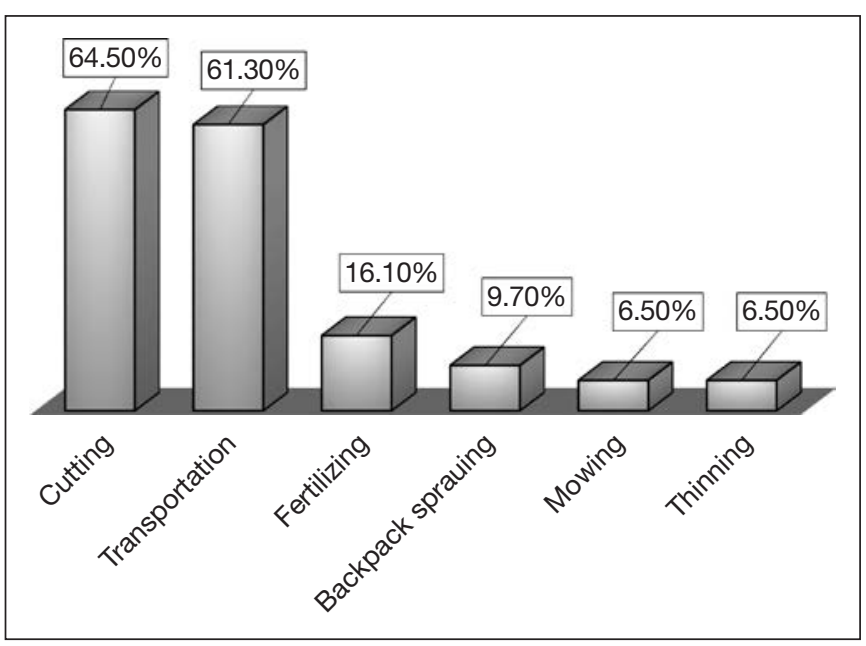

Figure 1. Main tasks considered painful and tiring in banana farming

The main tasks considered painful and tiring were cutting (64.5\%), banana bunch transportation $(61.3 \%)$ and fertilization (16.1\%), in general, because they require inappropriate postures and repetitive movements. Also, $94.4 \%$ of the workers were employed and $5.5 \%$ were self-employed, but the production modes were very similar among them as regards the physical demands of the work.

\section{DISCUSSION}

The rural properties of the study are small, but they are important in the regional agricultural and economic production. Most of the rural banana farming workers in this study were male, aged between 20 and 49 years, with low schooling. According to preliminary data from the 2017 Agricultural Census, only $14 \%$ of rural workers in Brazil are literate, $43 \%$ had only elementary school and only $14 \%$ had concluded high school $^{17}$. Regarding the employment contract, almost one-third of the workers had an informal employment contract. Informal work is a characteristic that is present in rural areas and is also related to low schooling ${ }^{18,19}$. The average time on the job in banana farming was 12 years. None of them reported working time for less than 12 months.

Rural workers have a much higher risk for musculoskeletal disorders in work activities compared to other occupations ${ }^{8}$. In this study, musculoskeletal disorders were predominant in the lumbar spine, shoulders and knees. The spine is the most affected region in rural workers, followed by the upper and lower limbs 9 . The lumbar spine is most affected mainly due to manual lifting and transportation of loads, as they perform repetitive movements with trunk flexions and rotations ${ }^{20}$. A relationship was also found between musculoskeletal disorders and work processes in fruit growing, with manual lifting and carrying of loads, sudden movements, exacerbated trunk flexion and biomechanical-postural misalignment ${ }^{7,9,21-23}$.

In the tasks of cutting, transportation, fertilizing, backpack spraying, mowing, and thinning related to banana farming, there is a physical and repetitive movement requirement. Because the banana is a delicate fruit, the whole process of cultivation and harvesting requires great caution, demanding greater muscle strength and motor coordination of workers ${ }^{11}$. In the production of melon, tomatoes, walnuts, grapes and cotton, the presence of musculoskeletal disorders was evidenced mainly in the packing, weeding, harvesting, pruning and cutting tasks, and in the operation of agricultural machinery ${ }^{9}$. Repetitive activities using hand tools, lateral trunk flexion or inclination movements, squats, and working hours over 40 hours per week were also associated with a higher prevalence of chronic musculoskeletal pain ${ }^{7,9,10,23}$.

In addition, over-tiredness and muscle fatigue were also reported by the study participants. Muscle fatigue and over-tiredness are usually associated with weight carrying, use of tools such as hoe and backpack pump for pesticide spraying as they are heavy ${ }^{8}$. Muscle can mean a warning condition for the body so that workers do not continue to perform the job function $^{24}$. In banana farming, exposure to physical, chemical, biological, and ergonomic workloads was observed, as well as long working hours, the pressure to reach productivity goals, and low wages ${ }^{12}$.

The study had limitations related to the sample size and because it was conducted in only one region that did not allow generalization for all banana farming workers. However, there are few studies related to banana farming work in Brazil and about the health of these workers.

\section{CONCLUSION}

Workers reported musculoskeletal disorders predominantly in the lower back, shoulders and knees. There were tasks considered painful and/or tiring, linked to cutting, transporting, fertilizing, spraying pesticides, mowing and thinning. There is a need for investigations and deepening aimed at the health of workers in banana farming.

\section{ACKNOWLEDGMENTS}

To São Paulo State Research Support Foundation (FAPESP).

\section{REFERENCES}

1. Bevan S. Economic impact of musculoskeletal disorders (MSDs) on work in Europe. Best Pract Res Clin Rheumatol. 2015;29(3):356-73.

2. Gerr F, Fethke NB, Merlino L, Anton D, Rosecrance J, Jones MP, et al. A prospective study of musculoskeletal outcomes among manufacturing workers: I. Effects of physical risk factors. Hum Factors. 2014;56(1):112-30.

3. INSS. Instituto Nacional de Seguridade Social. Boletim estatístico da previdência social. Secretaria de Políticas de Previdência Social. 2018;23(10):1-62.

4. Brasil. Ministério da Saúde. Secretaria de Vigilância em Saúde. Departamento de Vigilância em Saúde Ambiental e Saúde do Trabalhador. Dor relacionada ao trabalho: lesōes por esforços repetitivos (LER)/distúrbios osteomusculares relacionados ao trabalho [Internet]. Editora do Ministério da Saúde. 2012. 1-70p. Available from: http:// portalms.saude.gov.br/vigilancia-em-saude/publicacoes.

5. Viegas LR, Almeida MM. Perfil epidemiológico dos casos de LER/DORT entre trabalhadores da indústria no Brasil no período de 2007 a 2013. Rev Bras Saúde Ocup. 2016;41(22):1-10.

6. Jansson C, Alexanderson K. Sickness absence due to musculoskeletal diagnoses and risk of diagnosis-specific disability pension: a nationwide Swedish prospective cohort study. Pain. 2013;154(6):933-41.

7. Osborne A, Blake C, Fullen BM, Meredith D, Phelan J, McNamara J, et al. Prevalence 
of musculoskeletal disorders among farmers : a systematic review. Am J Ind Med. 2012;55(2):143-58.

8. Oliveira KN, Bezerra LR, Bezerra MA, Oliveira KN, Carneiro CT. Labor fatigue in rural workers. Rev Rene. 2013;14(5):866-76.

9. Xiao H, McCurdy SA, Stoecklin-Marois MT, Li CS, Schenker MB. Agricuktural work and chronic musculoskeletal pain among LAtino farm workers: the MICASA study. Am J Ind Med. 2014;56(2):216-25.

10. Osborne A, Blake C, Meredith D, Kinsella A, Phelan J, McNamara J, et al. Work-related musculoskeletal disorders among Irish farm operators. Am J Ind Med. 2013;56(2):235-42.

11. Takayama L, Merino GS, Merino EA, Garcia LJ, Cunha JM, Domenech SC. Hand tool project requirements: the case of banana cultivation and its physical demands (OWAS). Prod Manag Dev. 2015;13(2):119-30.

12. Rocha MM, Rigotto RM. Produção de vulnerabilidades em saúde: o trabalho das mulheres em empresas agrícolas da Chapada do Apodi, Ceará. Saúde em Debate. 2017;41(Especial):63-79.

13. Pinheiro FA, Troccoli BT, Carvalho CV. [Validity of the Nordic Musculoskeletal Questionnaire as morbidity measurement tool]. Rev Saude Publica. 2002;36(3):30712. Portuguese, English.

14. Cordeiro GP, Amorim M, Ronquim CC. Mudança de uso e ocupação da terra no município de Registro, SP, entre os anos de 1987 e 2017. CIIC. 2017;1-10.

15. Bongaarts J. The State of Food and Agriculture Leveraging Food Systems for Inclusive Rural Transformation. Vol. 19, FAO. Food and Agriculture Organization of The United Nations. 2017. 204p.
16. EMBRAPA. Empresa Brasileira de Pesquisa Agropecuária. Produção de bananas no Brasil [Internet]. 2013. Available from: http://www.cnpmf.embrapa.br.

17. IBGE. Censo Agro 2017: dados preliminares [Internet]. Instituto Brasileiro de Geografia e Estatística. 2018. Available from: https://censoagro2017.ibge.gov.br/templates/censo_agro/resultadosagro/index.html.

18. Rosa LA, Navarro VL. Trabalho e trabalhadores dos canaviais: perfil dos cortadores de cana da regiấo de Ribeirấo Preto (SP). Cad Psicol Soc do Trab. 2014;17(1):143-60. Available from: https://censoagro2017.ibge.gov.br/templates/censo_agro/resultadosagro/index.html.

19. Werlang R, Mendes JM. Pluriatividade no meio rural: flexibilização e precarização do trabalho na agricultura familiar. Em Pauta. 2016;14(38):140-63. Available from: http://www.e-publicacoes.uerj.br/index.php/revistaempauta/article/view/27857

20. Biazus M, Moretto CF, Pasqualotti A. Relationship between musculoskeletal pain complaints and family agriculture work. Rev Dor. 2017;18(3):232-7.

21. Martins AJ, Ferreira NS. A ergonomia no trabalho rural. Rev Eletrôn Atualiza Saúde. 2015;2(2):125-34.

22. Abrahão RF, Tereso MJ, Gemma SF. A Análise Ergonômica do Trabalho (AET) aplicada ao trabalho na agricultura: experiências e reflexóes. Rev Bras Saúde Ocup. 2015;40(131):88-97.

23. Osborne A, Finnegan G, Blake C, Meredith D, McNamara J, Phelan J, et al. An evaluation of low back pain among farmers in Ireland. Occup Med. 2013;63(1):53-9.

24. Costa CK, Lucena NM, Tomaz AF, Másculo FS. Avaliação ergonômica do trabalhador rural: enfoque nos riscos laborais associados à carga física. Gestão da Produção, Operaçōes e Sist. 2011;6(2):101-12. 